\title{
A Study of Networking and Information Exchange Factors Influencing User Participation in Niche Social Networking Sites
}

\author{
Carlos Andres Osorio, University of Manizales, Manizales, Colombia
}

Savvas Papagiannidis, Newcastle University Business School, Newcastle Upon Tyne, UK

\begin{abstract}
This article tests a number of networking and information exchange factors that may influence users' participation in niche social networking sites (SNS). The factors identified in the literature review as influential for participation in social networking sites were implemented in a model tested using quantitative data from 152 users. Gratifications related to socialising, self-status seeking, social support, and learning and innovativeness were identified as significant for participating in niche SNS. As only a subset of the general purpose SNS gratifications were found to be of statistical significance for niche sites, it is suggested that further research that includes a wider set of factors is necessary to determine the similarities and differences between gratifications influencing participation in general purpose and niche SNS.
\end{abstract}

\section{KEYWORDS}

Information Exchange Factors, Networking Factors, Niche Social Networking Sites, Social Media, Social Networking Sites, User Participation, Uses and Gratifications Theory

\section{INTRODUCTION}

Users are a critical resource for the success of any social networking site (SNS) (Xu et al. 2014). Achieving users' participation in SNS is considered to be one of the main factors in having a sustainable community in which users remain engaged over time. For this reason, researchers and practitioners are interested in finding what the factors influencing the participation in the network are. So far, research has had a strong focus on large SNS, which are mostly associated with general purpose SNS like Facebook and Twitter (Leskovec et al. 2008, Foregger 2008, Goggins et al. 2011, Smock et al. 2011, Tosun 2012, Kourouthanassis et al. 2015, Chen 2014, Yang and Lin 2014) General purpose networks are only part of the SNS world, which also includes niche SNS (Boyd and Ellison 2008). Niche SNS seek to narrow audiences by focusing on characteristics of the population, activities, identity and/or affiliations (Boyd and Ellison, 2008). Examples of niche SNS include Beautifulpeople.com, which is a network oriented to good looking people, Cafemom.com, which is oriented to women who are or who are going to be mothers, and Mychurch.org, which is oriented to Christian people.

One of the most accepted definitions of what a social networking site is was given by Boyd and Ellison (2008), who defined an SNS as "web-based services that allow individuals to (1) construct a public or semi-public profile within a bounded system, (2) articulate a list of other users with 
whom they share a connection, and (3) view and traverse their list of connections and those made by others within the system" (Boyd and Ellison, 2008, p. 2). This definition implies that the scope of the network is defined by the system, which these authors use later to differentiate between general purpose and niche SNS. The main difference relies on the purpose of the SNS, wherein the niche ones focus on characteristics of the population as noted above, narrowing their public to people with those characteristics or people interested in what the network is about. Niche SNS are gaining part of the market due precisely to their private nature (Bhappu and Schultze 2018, Calero-Valdez et al 2018, Crawford et al 2017, Kwon et al 2017, Lim, et al 2018). An additional fact arising is that Facebook, which is the most representative example of a general purpose SNS, has been losing a significant amount of users recently, not only due to privacy issues such as Cambridge Analytica, but also due to generational change (Castillo, 2018; Welch, 2018), which helps to show how people prefer to be with others who are similar to them, known as homophily (Kim, Lee, \& Bonn, 2016; Kwon et al., 2017). Since SNS are now part of our everyday routine, if people leave Facebook, they will go to another SNS, and that is where niche SNS become an alternative given the homophilous tendency of SNS users.

A parallel topic that arises with the study of SNS types is the study of SNS user types, which made it possible to discover that not everyone in the network behaves in the same way. Research like that developed by Brandtzæg (2012) proposed the following types of SNS users: Sporadics, Lurkers, Socializers, Debaters, which is similar to Constantinides et al (2010), who identified beginners, habitual Users, outstanding Users and Experts. These typologies contrast with the one proposed by Kilian et al, (2012) who, in their research about millennials, identified three clusters, namely: the restrained millennials, the entertainment-seeking millennials and the highly connected millennials. A similar approach was taken by Bulut and Doğan (2017), who identified advanced users, business-oriented users, communication seekers, and dawdlers. The classifications of SNS users shows a variety of approaches that this topic can take, producing different typologies. However, acknowledging the importance of user typologies, this topic goes beyond the scope of the present research, as we first have to find whether there is a difference between General Purpose and Niche SNS, and then we can start wondering about the types of users and their behaviours on the networks.

Due to the difficulty of accessing niche networks and their participants, it is not surprising that most research related to SNS participation typically revolves around general purpose SNS (Boyd and Ellison, 2008), leaving a gap for research into niche SNS. Given the differences in the nature and objectives of the two types of networks, it cannot be assumed that that the findings obtained for general purpose networks can be generalised for niche SNS. In fact differences in motivations for using SNS may exist even for general-purpose networks (Chung et al 2015, Gan \& Wang 2015, Kim and Jiyoung 2017, Phua et al. 2017, Krasnova 2017, Bae 2018, Bulut \& Doğan 2017). This paper's objective is to test this assumption, by examining a number of factors related to networking and information exchange identified for general purpose networks in a niche SNS environment. A better understanding of the reasons for using niche SNS and the differences from and similarities to general purpose ones could have significant implications. For example, it can inform the design and promotion of such networks when competing against the general purpose ones for users' attention. Given the above, in this project we adopted the uses and gratifications theory in order to study users' participation and, more specifically, the networking and information exchange factors that affect participation. The section following presents the relevant literature and the hypotheses to be tested. The paper then continues by outlining the methodology followed. In turn, it presents the results and findings of the analysis, which are put in the context of the previous studies. The paper concludes by considering future research avenues. 


\section{LITERATURE REVIEW}

One of the most significant indicators of SNS health is the proportion of active users, showing to what extent people are using the network, which can be complemented by the number of transactions or the amount of bandwidth required. Since the success of the network is mostly associated with participation, this has become the main focus for academics and practitioner research. The most common approaches to studying SNS participation are framed within the Theory of Planned Behaviour (TPB) (Hajli et al. 2015, Huang and Shiau 2015, Chen et al. 2016) and its variation, the Decomposed Theory of Planned Behaviour (Gironda and Korgaonkar 2014).

TPB aims to explain a particular human behaviour based on the intention, which is influenced by attitudinal beliefs and social norms and perceived behaviour control. According to TPB, attitudinal belief is orientated towards the favourability that the user has towards performing certain behaviour. Subjective norm is related to the social pressure to perform the behaviour, and perceived behavioural control (PBC) is related to the resources and opportunities available that may influence the behaviour (Ajzen, 1991). One of the main criticisms of the TPB is the unidimensionality of the factors involved in the standard TPB model for explaining belief formation (Hsu et al., 2006, Taylor and Todd, 1995). Closely related to the TPB, the Technology Acceptance Model has also been used to investigate participation (Shen 2015, Zhu et al. 2014, Xu et al. 2012, Lorenzo-Romero, Constantinides, \& Alarcóndel-Amo, 2011), Kwon and Wen 2010). This model, similarly to the TPB, predicts the behaviour based on the intention, considering attitude, perceived usefulness and perceived ease of use as antecedents. The parsimony of TAM is also one of its potential shortcomings as "it is unreasonable to expect that one model, and one so simple, would explain decisions and behaviour fully across a wide range of technologies, adoption situations, and differences in decision making and decision makers". (Bagozzi, 2007, p. 244). These theories find their origins in the Theory of Reasoned Action (Fishbein and Ajzen 1975), and are based on a cognitive/behavioural framework, aimed at predicting a behaviour (in this case SNS participation) based on the intention to perform that behaviour. A second stream of user participation research follows the Uses and Gratifications (U\&G) theory (Baek 2011, Giannakos et al. 2013, Yang and Lin 2014, Hsu et al. 2015, Chiu and Huang 2015b, Chiu and Huang 2015a, Wei et al. 2015, Bulut and Doğan 2017, Bae 2018, Gan \& Wang, 2015), which is based on psychosocial variables attempting to understand decision making processes about media (Rubin 2002). For this project a flexible approach such as the $U \& G$ theory was better suited to the aims of the project, as it includes a broader variety of constructs to understand users' participation.

The theory of uses and gratifications (U\&G) was postulated by Katz et al. (1973), based on sociological and psychological foundations. $U \& G$ has been used to explain the reasons for choosing one particular medium over another, suggesting that "people's needs influence their media selections; by seeking out and using specific media, people can meet these individual needs" (Foregger 2008, p. 2). The initial aims of U\&G theory were "a) to explain how people use media to gratify their needs, b) to understand motives for media behaviour, and c) to identify functions or consequences that follow" (Rubin 2002, p. 166). The original foundations of the model were proposed by Katz (as cited by Forreger 2008, p. 15) in five elements: “a) the audience is active, b) media choice depends on the audience's link between media and need gratification, $c$ ) media compete with other sources, both interpersonal and other media, for need satisfaction, $d$ ) audience members can self-report their needs, and e) value judgments of mass media content should be suspended until motives and gratifications are understood". These assumptions were revised by Rubin (Rubin 2002), who proposed an updated version based on the evolution of the media. The revised assumptions are: firstly, that communication behaviour is goal-directed, purposive, and motivated; secondly that people select media; thirdly that many factors guide our media selection; fourthly, that media compete with other channels for messages; and finally that people are typically more influential than media (Rubin 2002). The updated version considers the role of the user as a more active element, influenced mainly by needs, social and psychological factors and interpersonal interactions (Rubin 2002), along with the influence of 
the messages in the selection of the media. These assumptions fit with the aim of the research as people have the choice between general purpose and niche SNS to post what they want to say, as well as where to look for information and where to spend their time. Baek et al. (2011) stated that the main objective of this theory is to examine the motivations for media use, as well as the factors influencing these motivations by the users. Given the above, this paper focuses on the networking and information exchange factors that affect user intentions to participate in niche networks. These are discussed in more detail below.

\subsection{Networking and Information Exchange in Niche Networks}

\subsubsection{Networking and Socialising}

Networking and socialising are needs related to building and maintaining a network of contacts, as well as the benefits obtained from the contacts in the network. Bulut and Doğan (2017) studied how social gratifications such as socialisation and status seeking influence not only the usage of the networks, but also how they change according to the type of user present on the networks. The creation and maintenance of contacts in the social network looks to build the network of contacts either with relationships previously created (offline) or with new relationships created online (Cha 2010, Foregger 2008, Kim et al. 2010, Kim et al. 2011, Papacharissi and Rubin 2000, Park et al. 2009, Sangwan 2005, Xu et al. 2012, Hou 2011, Hsu et al. 2015, Bae 2018). Regarding the benefits obtained from the network, the gratifications of this type are related to what can be achieved (and/or offered) through the interaction with the members of the network. Thus, socialising is at the core of the gratifications for SNS participation (Goggins et al. 2011, Chen 2014, Cheung et al. 2011, Hsu et al. 2015, Park et al. 2009, Cocosila and Igonor 2015, Bulut and Doğan 2017. Due to the social needs of human beings, SNS have been gaining terrain as a space to develop and enhance the social activities that were held offline previously, hence having a positive influence on SNS participation. Associated to socialisation are the gratifications related to interconnectedness, which relates to expanding your network of contacts by finding people through existing contacts, having a direct relation with SNS usage (Foregger 2008, Ali-Hassan et al. 2015, Syn and Oh 2015). Another frequent use of SNS is maintaining of old ties (Foregger 2008, Joinson 2008, Ellison et al. 2007, Raacke and Bonds-Raacke 2008), which is exemplified by bringing friends from offline networks, such as friends from school or former work colleagues, and adding them to your online network. Along with the use of SNS to find their old friends, people are highly motivated to use SNS to find new friends (seeking friends) (Kim et al. 2011, Ellison et al. 2007, Huang 2008, Papacharissi and Rubin 2000, Smock et al. 2011).

Based on the presented literature we hypothesise that:

H: (1) Socialising, (2) interconnectedness, (3) maintaining old ties, (4) seeking friends, have a positive and significant effect on the intensity of participation in niche SNS.

Using SNS to share information with your whole network or part of it is a popular gratification. Among the examples are the changes in relationship status such as being in a relationship, break-ups, engagements, etc., or sharing photos from different events. Likewise, the groups are used to arrange events and resolve conflicts in the group (Dimmick et al. 2007, Baek et al. 2011, Ramirez Jr et al. 2008, Hsu et al. 2015).

Interpersonal utility (Cha 2010, Papacharissi and Rubin 2000, Wong 2012), which is related with the information that the user finds important for personal life, such as the opinion that other people have about him or her, information about social events or keeping up to date with what is going on in the user's circles. Following the utility of the SNS, there is an additional gratification related with the image that the user wants to project in the SNS, which is labelled self-status seeking (Park et al. 2009, Hsu et al. 2015), which has traditionally been presented as the efforts that people make to present themselves in a particular maner to others. The image that the user portrays in the network can be a real reflection of the user's life, or a desired image that the user wants to project, 
which is associated with belongingness and narcissistic behaviours (Schau and Gilly 2003, Pugh 2010, Zhao et al. 2008, Mehdizadeh 2010). In this regard, Chung et al (2017) presented the self-image, which is closely related to self-status seeking, as a "constant process of controlling and managing information to continuously deliver one's specific image to others" (p. 82), which can be connected with the finding of Baek et al. (2011), who found the likelihood for people to share information about themselves, with this information sharing having an impact on SNS usage. A final gratification in this group is seeking social support, which is very common in networks related with health issues like Ihadcancer.com, in which the members support each other by providing pastoral care as well as sharing treatments and medicines that have helped them to feel better, having a positive effect on network participation (Kim et al. 2011, Shen 2015, Hajli et al. 2015, Ridings and Gefen 2004, Wong 2012, Bae 2018). Chung et al (2017) argue that the more people interact with each other, the more they start creating this attachment to others, which allows them to extend and ask for help given the situation, which in turn strengthens the ties between them.

Based on the above we propose that:

H: (5) interpersonal utility, (6) self-status seeking, and (7) seeking social support have a positive and significant effect on the intensity of participation in niche SNS.

\subsubsection{Information Exchange}

Information exchange is a key motivation for participating in social networking sites, as studied by Chung et al. (2017), considering the number of members in the network, social interaction helping and self-image as predictors of this factor and Crawford et al. (2017), who focused on the self-status motivation of the user. This information could be about the user (i.e. personal information such as photos, list of contacts, movies, bands, among others) or information about specific interests or purposes, for example photography, astronomy, etc. Information exchange gratifications are related to the second type of information, considering the SNS as a repository of information about specific topics. For the information exchange, the user comes to the network either looking for information and the opinions of the members of the networks about topics of interest to them, or looking to acquire deeper knowledge of the topics discussed in the network (Cha 2010, Foregger 2008, Kim et al. 2011, Papacharissi and Rubin 2000, Huang 2008, Chung et al. 2012, Park et al. 2014, Chang and Chen 2014, Hsu et al. 2015, Park et al. 2015, Syn and Oh 2015, Yen 2016, Chung et al. 2015). This information seeking and exchange results in a new alternative type of web search known as "social search" (Lampe et al. 2006), as well as in a "social shopping" process (Kang and Johnson 2015), which is based on the opinions of the network members about specific topics.

Attached to the information seeking are the learning and knowledge gratifications, whereby it is expected that people will access better or specialised resources that are not usually shared in the general SNS groups, this being an attractive motivation to use the SNS (Cha 2010, Huang 2008, Kim et al. 2011, Papacharissi and Rubin 2000, Park et al. 2009, Chunngam et al. 2014, Lingreen et al. 2013, Syn and Oh 2015, Yen 2016). Innovativeness is a popular gratification in SNS (Huang 2008, Sangwan 2005, Park et al. 2015), which is related to the openness to new ideas (Cha 2010, Rogers 2003). The next factor is related to the convenience of the SNS as a tool to conduct specific activities. A representative example is the use of the SNS as a communication tool, making it possible to be in touch with other members of the network at a fraction of the cost paid when compared to other means. In addition to the money savings, there are some time and effort savings (Cha 2010, Dimmick et al. 2007, Foregger 2008, Kim et al. 2011, Papacharissi and Rubin 2000, Ramirez Jr et al. 2008, Dimmick et al. 2000, Huang 2008, Nyland 2007, Sangwan 2005).

Given the above, we put forward the following hypotheses:

H: (8) information seeking, (9) learning, (10) innovativeness and (11) communication gratifications have a positive and significant effect on the participation in niche SNS. 


\section{METHODOLOGY}

\subsection{Questionnaire design}

Studies grounded on $U \& G$ are typically based on questionnaires using Likert scales to collect data from primary sources (Lee et al. 2010, Cheung et al. 2011, Kim et al. 2010, Papacharissi and Rubin 2000). Following the example of previous research, a survey was adopted as the instrument for data collection using a Likert scale of five points. Due to the lack of research on niche SNS, this research adopted the constructs identified as influential in general purpose networks, when it came to networking and information seeking to develop the data collection instrument. Using these constructs was considered to be a good first approach to understanding niche SNS. Further research could potentially include new constructs or exclude constructs among those examined by this paper. The model implemented tested the relationship of each item with the user's participation in SNS. The questionnaire was tested in a pilot study and feedback was received about the length of the questionnaire and items with similar wording, with minor adjustments made before finalising the questionnaire. Given the nature of the research, a web-based survey was deemed appropriate for collecting data. Tables 1 and 2 present the constructs and items used in the questionnaire to collect data.

\subsection{Sampling}

Based on the gap and the research question for this study, the initial population framework was users of niche SNS. Following the definition of Boyd and Ellison (2008), a niche SNS is a network with a specific purpose and/or oriented to a specific target of the population. Thus, niche SNS could be networks from LinkedIn, which, despite its size, is oriented to professional purposes, to networks like Little Monsters, oriented to the fans of Lady Gaga. However, the very niche nature of these networks makes it difficult to map the population, as many of them are only known among the group of people who share the same interest. Looking for statistics to define a population framework, it was found that there is a lack of information about how many networks there are or how many users are registered in each of these networks. There are some private initiatives trying to generate network directories, but they are not reliable enough to create a full map of the population. Based on the above, it was deemed appropriate to use a non-probabilistic sampling method. Since the sampling framework was unknown, volunteer opportunity sampling was the most suitable alternative to reach niche network users. The sample was narrowed down to UK residents to ensure a minimum of experiential consistency. The invitations to participate in this research project were posted on different social media accounts as recommended by Hewson and Laurent (2012). In addition, a second strategy to collect data was based on identifying the main niche SNS platforms. From this search, Ning, SocialGo and Elgg were found to be popular options. The first group approached was the developers' community on these platforms, as they are usually the administrators of their own networks. The invitation to complete the questionnaire, including the link, was posted on these forums. Likewise, network administrators were contacted via email, requesting permission to post the invitation on their networks. Posting the invitation on an open forum was found to be a more effective strategy, compared to the option of the administrators, as they were reluctant to promote the questionnaire in their networks.

Of the 203 questionnaires completed over four months in Q3/2012, we filtered out those indicated using an SNS that was not a niche one or were outliers. The final samples used for the analysis had responses from 152 participants. $44 \%$ were from women and $56 \%$ were from men, so there was a relatively balanced composition of the sample regarding gender. The average age of participants was 29.53 years old (std. dev. $=11.01$ ). When it came to the occupation of the participants, $55.26 \%$ were students, $23.03 \%$ were full time employees, $10.53 \%$ were part-time employees and finally $9.21 \%$ were self- employed. From the results, LinkedIn was the most popular niche SNS, with 25 cases. This network is followed by QQ from China, with 14 respondents, academia with 10 and VKontackte with 7. These four networks represent $36.84 \%$ of the total respondents. Given the nature of niche 
Table 1. Niche SNS participation construct sources

\begin{tabular}{|c|c|c|c|c|c|c|}
\hline Gratifications & Acronym & Definition & Source & Items & $\begin{array}{l}\text { Niche } \\
\text { Mean }\end{array}$ & $\begin{array}{l}\text { Niche } \\
\text { Std. } \\
\text { Dev. }\end{array}$ \\
\hline Socialising & SOC & $\begin{array}{l}\text { Is based on the need } \\
\text { for and interest in } \\
\text { meeting and talking } \\
\text { with other people }\end{array}$ & $\begin{array}{l}\text { (Park et al. } \\
2009 \text { ) }\end{array}$ & 4 & 3.572 & 0.997 \\
\hline Interconnectedness & IC & $\begin{array}{l}\text { Finding connections } \\
\text { and information } \\
\text { through existing } \\
\text { contacts }\end{array}$ & (Foregger 2008) & 7 & 2.809 & 0.996 \\
\hline Maintaining old ties & MAT & $\begin{array}{l}\text { Keeping the } \\
\text { connection online } \\
\text { with friends known } \\
\text { from before }\end{array}$ & (Foregger 2008) & 5 & 2.845 & 1.174 \\
\hline Seeking friends & SFRIE & $\begin{array}{l}\text { Finding new } \\
\text { friends to exchange } \\
\text { information with }\end{array}$ & $\begin{array}{l}\text { (Kim et al. } \\
\text { 2011) }\end{array}$ & 2 & 3.552 & 0.955 \\
\hline Interpersonal utility & IPU & $\begin{array}{l}\text { The utility sought in } \\
\text { the interaction with } \\
\text { other people at a } \\
\text { relational level }\end{array}$ & $\begin{array}{l}\text { (Cha 2010, } \\
\text { Papacharissi and } \\
\text { Rubin 2000) }\end{array}$ & 8 & 3.580 & 0.853 \\
\hline Self-status seeking & STA & $\begin{array}{l}\text { Seeking and } \\
\text { maintaining the user's } \\
\text { personal status } \\
\text { through online group } \\
\text { participation }\end{array}$ & $\begin{array}{l}\text { (Park et al. } \\
\text { 2009) }\end{array}$ & 3 & 3.747 & 1.053 \\
\hline Seeking social support & SUP & $\begin{array}{l}\text { Obtaining emotional } \\
\text { support from their } \\
\text { group of contact }\end{array}$ & $\begin{array}{l}\text { (Kim et al. } \\
\text { 2011) }\end{array}$ & 3 & 2.477 & 1.183 \\
\hline Information seeking & INSK & $\begin{array}{l}\text { Searching for } \\
\text { information that is of } \\
\text { interest to the users, } \\
\text { such as activities } \\
\text { carried out by their } \\
\text { group of contacts }\end{array}$ & $\begin{array}{l}\text { (Papacharissi } \\
\text { and Rubin 2000, } \\
\text { Park et al. 2009, } \\
\text { Kim et al. 2011) }\end{array}$ & 5 & 3.570 & 0.898 \\
\hline Learning & LEARN & $\begin{array}{l}\text { Obtain information } \\
\text { and being educated } \\
\text { about a topic, and } \\
\text { learning new things }\end{array}$ & (Cha, 2010) & 4 & 2.618 & 1.076 \\
\hline Innovativeness & INNOV & $\begin{array}{l}\text { Individual's tendency } \\
\text { to be more receptive } \\
\text { to new ideas }\end{array}$ & (Cha, 2010) & 4 & 3.281 & 1.021 \\
\hline Communication convenience & COM-CON & $\begin{array}{l}\text { How SNS facilitates } \\
\text { the communication } \\
\text { process with other } \\
\text { people }\end{array}$ & (Cha 2010) & 4 & 3.290 & 0.853 \\
\hline Intensity of use & INT-USE & $\begin{array}{l}\text { Measures the } \\
\text { engagement of } \\
\text { the user with the } \\
\text { SNS based on the } \\
\text { integration of the } \\
\text { SNS with the user's } \\
\text { routine }\end{array}$ & $\begin{array}{l}\text { (Ellison et al. } \\
\text { 2007) }\end{array}$ & 5 & 3.411 & 0.915 \\
\hline
\end{tabular}


Table 2. Items used for each construct

\begin{tabular}{|c|c|c|}
\hline Gratification & Acronym & Items \\
\hline \multirow{4}{*}{ Socialising } & soc1 & To stay in touch with people I know \\
\hline & soc2 & To meet interesting people \\
\hline & soc3 & To talk about something with others \\
\hline & soc4 & To get peer support from others \\
\hline \multirow{7}{*}{ Interconnectedness } & ic1 & To network with others \\
\hline & ic2 & To see who knows who \\
\hline & ic3 & To look at pictures of my "friends' friends" \\
\hline & ic4 & To see who my contacts and I have in common \\
\hline & ic5 & To see if my contacts and I know the same people \\
\hline & ic6 & To see how everyone is connected \\
\hline & ic7 & To see where people know each other from \\
\hline \multirow{5}{*}{ Maintain/Establish old ties } & mat1 & To keep in touch with old friends \\
\hline & mat2 & To contact out-of-state friends \\
\hline & mat3 & To track down old friends \\
\hline & mat4 & To see where people are at now \\
\hline & mat5 & To maintain old friendships \\
\hline \multirow{2}{*}{ Seeking Friends } & sfrie1 & To hang out with people I enjoy \\
\hline & sfrie2 & To talk with people with the same interests \\
\hline \multirow{8}{*}{ Interpersonal utility motive } & ipu1 & To meet new people \\
\hline & ipu2 & To belong to a group \\
\hline & ipu3 & To express myself freely \\
\hline & ipu4 & Because I wonder what other people said \\
\hline & ipu5 & To keep contact with my contacts \\
\hline & ipu6 & To feel involved with what's going on with other people \\
\hline & ipu7 & To keep my contacts up-to-date \\
\hline & ipu8 & To strengthen my relationships with my contacts \\
\hline \multirow{3}{*}{ Self-status seeking } & sta1 & Because it makes myself look cool \\
\hline & sta2 & To develop my career through group participation \\
\hline & sta3 & Because I feel peer pressure to participate \\
\hline \multirow{3}{*}{ Seeking Social Support } & sup1 & To let out my emotions easily to others who will understand me \\
\hline & sup2 & To talk out my problems and get advice \\
\hline & sup3 & To let others know I care about their feelings \\
\hline \multirow{5}{*}{ Information seeking } & insk1 & To look for information \\
\hline & insk2 & To get information for free \\
\hline & insk3 & Because it is easier to search for information \\
\hline & insk4 & To see what is out there \\
\hline & insk5 & Because it is a new way to do research \\
\hline \multirow{4}{*}{ Learning motive } & learn1 & Because it lets me explore new things \\
\hline & learn2 & Because it extends my mind \\
\hline & learn3 & Because it advances my knowledge \\
\hline & learn4 & Because it opens me up to new ideas \\
\hline \multirow{4}{*}{ Innovativeness } & innov1 & Because I am very curious about how things work \\
\hline & innov2 & Because I like to experiment with new ways of doing things \\
\hline & innov3 & Because I like to take a chance \\
\hline & innov4 & Because I like to be around unconventional people who dare to try new things \\
\hline \multirow{4}{*}{ Communication convenience } & com-con 1 & Using SNS makes me more efficient \\
\hline & com-con 2 & Using SNS helps me accomplish things more quickly \\
\hline & com-con 3 & Using SNS makes my life easier \\
\hline & com-con 4 & Using SNS would be useful in my life \\
\hline \multirow{5}{*}{ Intensity of use } & Int-use 1 & This niche network is part of my everyday activity \\
\hline & Int-use2 & I am proud to tell people I'm on this niche network \\
\hline & Int-use 3 & I feel out of touch when I haven't logged onto this niche network for a while \\
\hline & Int-use 4 & I feel I am part of the this niche network community \\
\hline & Int-use5 & I would be sorry if this niche network shut down \\
\hline
\end{tabular}

SNS, there is a wide variety of networks with few cases. Examples of these niche SNS used by the respondents are DevianArt, Path, Naijapals, and Tony Arts. More details about the demographic variables are presented in Table 3. 
Table 3. Sample demographics

\begin{tabular}{|c|c|c|c|c|c|}
\hline Characteristic & Frequency & $\%$ & Characteristic & Frequency & $\%$ \\
\hline \multicolumn{3}{|l|}{ Gender } & \multicolumn{3}{|c|}{ Age } \\
\hline Male & 85 & $55.92 \%$ & Blank & 1 & $0.66 \%$ \\
\hline Female & 67 & $44.08 \%$ & $<19$ & 6 & $3.95 \%$ \\
\hline Total & 152 & $100 \%$ & $20-29$ & 89 & $58.55 \%$ \\
\hline \multicolumn{3}{|l|}{ Employment Status } & $30-39$ & 37 & $24.34 \%$ \\
\hline Paid full-time employment & 35 & $23.03 \%$ & $40-49$ & 5 & $3.29 \%$ \\
\hline Paid part-time employment & 16 & $10.53 \%$ & $>50$ & 14 & $9.21 \%$ \\
\hline Self-employment & 14 & $9.21 \%$ & Total & 152 & $100 \%$ \\
\hline Unemployed & 3 & $1.97 \%$ & \multicolumn{3}{|c|}{ Educational attainment } \\
\hline Student & 84 & $55.26 \%$ & Primary School & 0 & $0.00 \%$ \\
\hline Total & 152 & $100 \%$ & High School & 13 & $8.55 \%$ \\
\hline \multicolumn{3}{|l|}{ Annual household income } & $\begin{array}{l}\text { Technical } \\
\text { Education }\end{array}$ & 5 & $3.29 \%$ \\
\hline Less than $£ 10,000$ & 50 & $32.89 \%$ & Undergraduate & 53 & $34.87 \%$ \\
\hline$£ 10,000$ to $£ 19,999$ & 21 & $13.82 \%$ & Postgraduate & 68 & $44.74 \%$ \\
\hline$£ 20,000$ to $£ 29,999$ & 16 & $10.53 \%$ & Doctorate degree & 13 & $8.55 \%$ \\
\hline$£ 30,000$ to $£ 39,999$ & 24 & $15.79 \%$ & Total & 152 & $100 \%$ \\
\hline$£ 40,000$ to $£ 49,999$ & 12 & $7.89 \%$ & & & \\
\hline$£ 50,000$ to $£ 59,999$ & 10 & $6.58 \%$ & & & \\
\hline$£ 60,000$ or more & 19 & $12.50 \%$ & & & \\
\hline Total & 152 & $100 \%$ & & & \\
\hline
\end{tabular}

\subsection{Analysis}

The information was cleaned and the constructs were tested regarding validity. The diagonal of Table 3 lists the Cronbach's Alpha for each construct. A Kaiser-Meyer-Olkin (KMO) Test and a factor analysis were also conducted (Table $4 \& 5$ ). A multiple regression analysis was used to analyse the data. The regression model was run in SPSS, starting with all the variables proposed above using the stepwise method. The Durbin-Watson coefficient was 2, meaning that there were no autocorrelation issues, and the VIF values for all the significant variables were below 1.55, suggesting that there were no collinearity issues. The residuals showed no evident patterns. All these considerations suggested that the model complied with the assumptions of the regression model.

\section{RESULTS}

Table 6 presents the correlation coefficients of the variables included in the model, as well as its reliability coefficients.

The value of $\mathrm{R}^{2}$ for the regression was $41.2 \%$. Based on the results obtained, the significant factors were found to be the socialising, self-status seeking, seeking social support and learning and innovativeness gratifications (Figure 1). These results show that users prefer to use the niche SNS for specific purposes and interact with like-minded people, which is the purpose of the niche SNS. Likewise, the results show that gratifications related with creating/maintaining the network of 
Table 4. KMO and Bartlett's test

\begin{tabular}{|l|l|l|}
\hline \multicolumn{2}{|c|}{ KMO and Bartlett's test } \\
\hline Kaiser-Meyer-Olkin Measure of Sampling Adequacy & 0.865 \\
\hline \multicolumn{2}{|l|}{} \\
\hline \multirow{2}{*}{ Bartlett's test of sphericity } & Approx. Chi-Square & 7802.795 \\
\cline { 2 - 3 } & df & 1431 \\
\cline { 2 - 3 } & Sig. & .000 \\
\hline
\end{tabular}

contacts are not significant for niche SNS, suggesting that these gratifications apply only to general purpose networks.

\section{DISCUSSION}

The model proposed for testing the motivations for participating in niche SNS aimed to study the direct relationship of each construct with the intensity of use. Out of the 11 gratifications tested, five were found to be significant. Keeping in mind that the model aimed to test whether the gratifications identified for general purpose networks applied to niche ones, it was no surprise that only a few variables were not as relevant and were eventually rejected. This suggests that there is indeed a difference in the motivations to participate in general purpose networks and niche SNS, contrary to the current practice that treats all networks as the same (Wilson et al. 2012) Further research on niche SNS is needed if we are to understand user behaviour in these networks better and more reliably.

More specifically, the socialising hypothesis related to the social nature of the SNS, which regardless of the type, niche or general purpose, is still a key factor explaining why a user participates in an SNS as Bulut and Doğan (2017) show in their research. This is reflected in the value of its coefficient, which is the largest among the factors tested. Users participate in niche SNS for social reasons, but not the typical reasons such as people looking to connect with old contacts or to meet new people for the sake of it. This argument is supported by the rejection of the interconnectedness and maintaining old ties, which are factors associated with these behaviours. Considering these results, it can be argued that socialising, as presented by Park (2009), is more about sharing time and opinions with like-minded people on topics that they are interested in, which fits with the purpose of a niche SNS.

The second significant factor was support sought and/or provided by people sharing the same issues, interest, goals or tastes (Cha 2010, Foregger 2008, Kim et al. 2011, Li et al. 2015, Hajli et al. 2015, Shen 2015, Wong 2012). As an example, one may consider a health-related network called tudiabetes.org, which is a network oriented to people dealing with diabetes, also providing a platform to share experiences with other people with the same condition. Kim et al. (2011) argue that the social support is rooted in the need to belong to a community of people with similar characteristics to the user created by a sense of identification, and this is supported by Kwon et al (2017), Shen (2015), and by Wong (2012). This identification with the group is reflected in the search for encouragement and companionship from the people in the network (either previous contacts or new contacts made in the network). This identification enables them to express themselves more openly, as people in the group can understand what the person is looking for more easily. Also, sharing the same interest/ condition makes it possible for them to be less concerned about being judged or misinterpreted by other people (Chung et al. 2015). A common practice in general purpose networks is to put together all the contacts, mixing family, friends, colleagues, etc. Still, when people need support, they prefer to appeal to those who can understand them better. A niche SNS could potentially be a safe place in which the users can express themselves freely, as these networks consist of people with similar characteristics to the user (from physical condition, to similar interests, etc.). 
Table 5. Factor analysis

\begin{tabular}{|c|c|c|c|c|c|c|c|c|c|c|}
\hline & \multicolumn{10}{|c|}{ Component } \\
\hline & ipu & mat & ic & int use & sta & learn & com-con & sup & innov & soc \\
\hline Int_use1 & & & & 0.765 & & & & & & \\
\hline Int_use2 & & & & 0.710 & & & & & & \\
\hline Int_use 3 & & & & 0.769 & & & & & & \\
\hline Int_use4 & & & & 0.814 & & & & & & \\
\hline Int_use5 & & & & 0.754 & & & & & & \\
\hline soc1 & & & & & & & & & & \\
\hline $\operatorname{soc} 2$ & & & & & & & & & & 0.724 \\
\hline $\operatorname{soc} 3$ & & & & & & & & & & \\
\hline soc4 & & & & & & & & & & 0.339 \\
\hline ic1 & & & 0.261 & & & & & & & \\
\hline ic2 & & & 0.769 & & & & & & & \\
\hline ic3 & & & 0.322 & & & & & & & \\
\hline ic4 & & & 0.797 & & & & & & & \\
\hline ic5 & & & 0.819 & & & & & & & \\
\hline ic6 & & & 0.785 & & & & & & & \\
\hline ic7 & & & 0.746 & & & & & & & \\
\hline mat1 & & 0.866 & & & & & & & & \\
\hline mat2 & & 0.784 & & & & & & & & \\
\hline mat3 & & 0.783 & & & & & & & & \\
\hline mat4 & & 0.588 & & & & & & & & \\
\hline mat5 & & 0.858 & & & & & & & & \\
\hline sfrie1 & & & & & & & & & & \\
\hline sfrie2 & & & & & & & & & & \\
\hline ipu1 & 0.410 & & & & & & & & & \\
\hline ipu2 & 0.734 & & & & & & & & & \\
\hline ipu3 & 0.778 & & & & & & & & & \\
\hline ipu4 & 0.779 & & & & & & & & & \\
\hline ipu5 & 0.755 & & & & & & & & & \\
\hline ipu6 & 0.656 & & & & & & & & & \\
\hline ipu7 & 0.792 & & & & & & & & & \\
\hline ipu8 & 0.755 & & & & & & & & & \\
\hline sta1 & & & & & 0.718 & & & & & \\
\hline sta2 & & & & & 0.803 & & & & & \\
\hline sta3 & & & & & 0.580 & & & & & \\
\hline sup1 & & & & & & & & 0.786 & & \\
\hline sup2 & & & & & & & & 0.748 & & \\
\hline sup3 & & & & & & & & 0.739 & & \\
\hline insk1 & & & & & & & & & & \\
\hline insk2 & & & & & & & & & & \\
\hline insk3 & & & & & & & & & & \\
\hline insk4 & & & & & & & & & & \\
\hline insk5 & & & & & & & & & & \\
\hline learn1 & & & & & & 0.837 & & & & \\
\hline learn2 & & & & & & 0.904 & & & & \\
\hline learn3 & & & & & & 0.906 & & & & \\
\hline learn4 & & & & & & 0.716 & & & & \\
\hline innov1 & & & & & & & & & 0.739 & \\
\hline innov2 & & & & & & & & & 0.556 & \\
\hline innov3 & & & & & & & & & 0.720 & \\
\hline innov4 & & & & & & & & & 0.738 & \\
\hline pu1 & & & & & & & 0.826 & & & \\
\hline $\mathrm{pu} 2$ & & & & & & & 0.800 & & & \\
\hline pu3 & & & & & & & 0.798 & & & \\
\hline pu4 & & & & & & & 0.782 & & & \\
\hline
\end{tabular}







Figure 1. The model and results

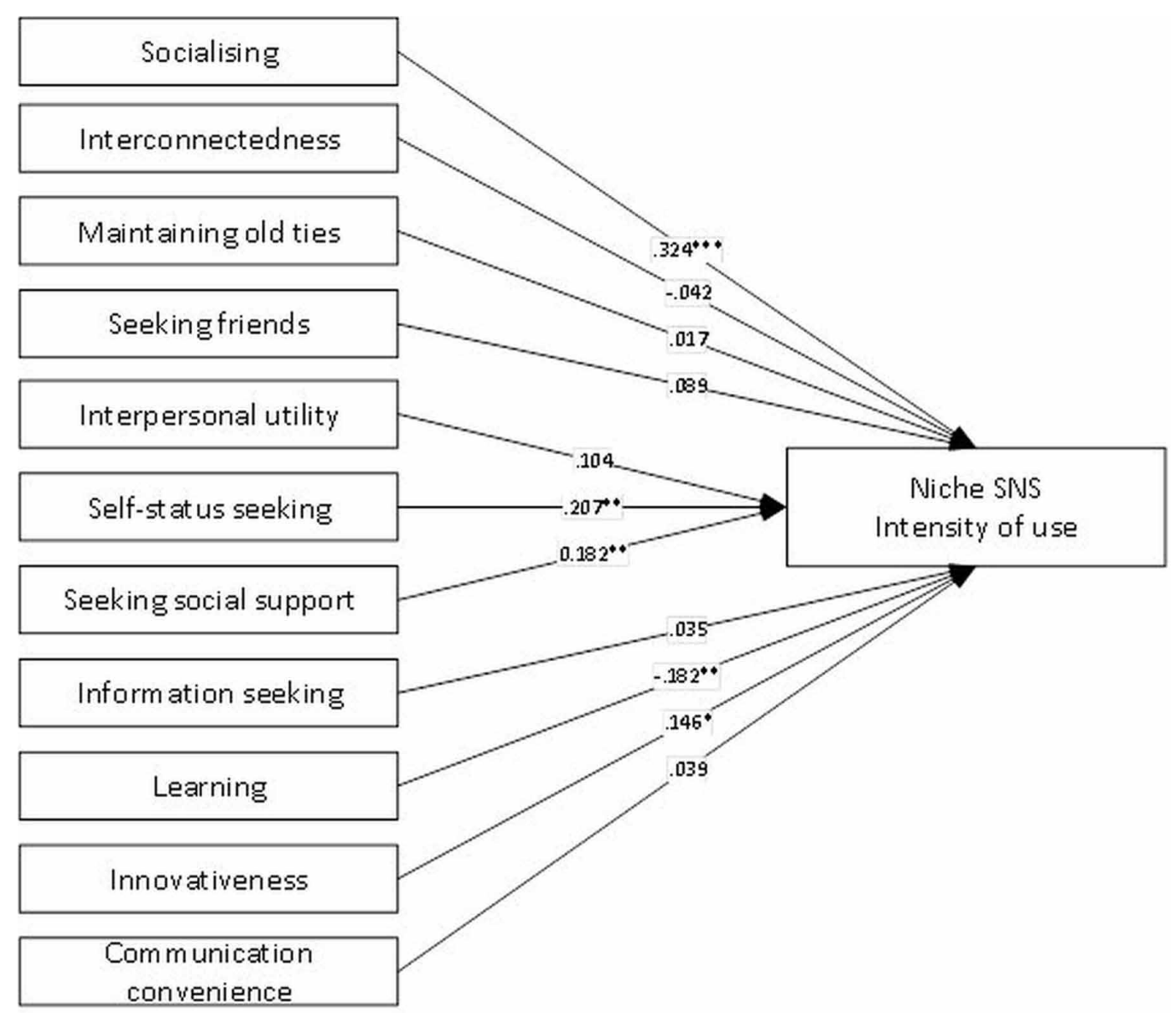

The third gratification was self-status seeking, which is related to building and maintaining an image through the continuous participation in a group. This participation is based on the identification with the group and the desire to be acknowledged as part of the group (Nadkarni and Hofmann 2011, Kilian et al, 2012). Sangwan (2005) argues that the self-status seeking gratification looks to reaffirm the self-identity by being recognised as the image the user is projecting, as well as interacting with (influential) people in the group that otherwise would be difficult to meet. The identity is reaffirmed by the acknowledgement of one's status as a member of the group, feeding the self-satisfaction need. In this regard, Bulut and Doğan (2017) stressed the importance of status seeking as part of the reinforcement of personal values and the creation of a social identity, which is part of the identification process. This identification process points to belongingness as one of the needs that people look for when participating in SNS (Krasnova et al. 2008, Pai and Arnott 2012, Smock et al. 2011, Zolkepli and Kamarulzaman 2015, Hsu et al. 2015, Nadkarni and Hofmann 2011, Wong 2012). The belongingness is fostered by the interaction with people that otherwise it would be difficult to be in contact with, due to geographical distance, different social circles, etc. The belongingness has been studied by Chung et al (2016) by the attachment that the person has to a group, which makes them share information that they will not share with everybody. This finding is in line with Tan's (Tan et al. 2015) argument about the importance of weak ties over the strong ones regarding trust and identification with a specialised group. It is important to highlight that the identity projected in 
the network does not necessarily match the identity of the person in real life (Zhao et al. 2008, Wong 2012, Tosun 2012). In fact, a user can have accounts on different networks for different purposes (Mital and Sarkar 2011), having the chance to create a different identity on each one of them, or even create several users in the same network. Each can have a different identity, as in the case of people with different Facebook accounts or the current trend of fake intagram accounts (finstagram) used by people to post their private photos (Carman 2018, The Guardian 2017). This point is important, as when users join due to peer or superior pressure, they may not necessarily project their real self (Tosun 2012). The same may apply to those users participating in niche networks for operational reasons, e.g. trying to get some benefit from the network, such as information, contacts or knowledge. These users will participate in the network just to get what they are looking for. There may exist conditions for admitting new users, like the case of aSmallworld, which is an SNS for millionaires, and the people are accepted only if they are invited by a current member of the network.

The fourth gratification emerging as an important factor for understanding participation in a niche SNS was learning. Contrary to prior research (Cha, 2010, Foregger 2008), the coefficient for this variable was negative. Considering that self-status seeking was found to be a significant factor, one may interpret this as evidence that users on niche networks are more interested in sharing in order to be recognised as experts by their peers, rather than learning. Those who participate in niche SNS may want to position themselves as experts on the topic more than on the learner role. This situation can be seen on LinkedIn, on which users demonstrate their expertise not only using the information presented on their profiles, but also by drawing kudos from the recommendations of other users. Users participate in niche SNS as these networks provide information about a specific topic, as well as access to people who know about the topic (Cha 2010, Huang 2008, Kim et al. 2011, Papacharissi and Rubin, 2000 Park et al. 2009). The resources (people and information) that people perceive they will find in the niche SNS are something that they will rarely find in the general-purpose networks. Posting specialised views on niche networks may have been more appreciated compared to general purpose networks, while the highly focused discussion would help engage more members, encouraging them not only to read, but also to contribute to the conversation.

Finally, innovativeness follows the use of niche SNS for specific purposes, in this case as a source of innovative ideas, alternative points of view, or information that can lead to new developments. Cha (2010) portrays innovativeness as the tendency of the person the be more open or receptive to new ideas. Niche SNS contain information that is interesting for their members, and that users can post and where they can find information that is not easy to find elsewhere. Users participating in these networks are looking for new ideas, to enrich and receive feedback about their ideas, or to propose initiatives that can be found to be interesting for the other members of the network. The information sharing was found important by Baek et al. (2011) to explain the SNS usage, as it allowed information exchange and ideas that could be useful. Niche SNS can offer more opportunities to find specific information, ideas and projects to be noticed by the right audience than when posted on general purpose networks, where they could go under the radar and be ignored along with the other sea of posts presented on the timeline.

\section{CONCLUSION}

This research has provided evidence that there may be potentially different factors influencing the participation in general purpose networks and niche SNS. In turn, this suggests that general purpose and niche SNS cannot be assumed to be similar in nature or treated in the same manner.

The literature review suggested that socialisation and information exchange gratifications played an important role in user participation. A number of factors related to these gratifications were tested on niche SNS users. Socialising, social support, self-status seeking, learning and innovativeness were the main factors that motivated users to participate in niche SNS. Socialising, social support and selfstatus seeking gratifications suggested that belongingness was an underlying factor in participating, 
following the findings of Park et al (2009) about SNS usage and Chung et al (2016) about attachment. Users want to be with people who share the same interest; they want to be part of the groups of like-minded people, which aligns with the concept of homophily (Leskovec et al. 2008, Goggins et al. 2011). In niche SNS, Identity plays an important role as people participate in the SNS as a way of reaffirming their own identity (real or desired) through the participation in the network, which is related with research on self-status seeking (Park et al. 2009, Chung et al 2009) This triggers the identification process, which enables users to share the situation they are going through more easily, looking for support from others in the network. In the same vein, users reaffirm their identity through group validation. The results are related to the self-status seeking and learning gratifications. They suggest that users may participate in niche SNS as an opportunity to demonstrate their knowledge about a specific topic (self-status seeking). Niche SNS present a good opportunity for users not only to access specialised information, but also to interact with other similarly-minded users interested in the same topics, integrating the self-status seeking and social support characteristics in this gratification. These gratifications are complemented by innovativeness. Users may utilise niche SNS as a source for new ideas or as an outlet to present their ideas or projects to a public that has a higher chance of being interested in it or hearing about it, following Baek et al.'s (2011) results.

As it is becoming more frequent for business or interest groups to establish their own social networks, the managerial implications of this research are oriented towards potential ways of designing such SNS and promoting user participation in them. People are present in niche SNS not only because of the socialisation gratifications, but because they want to create links with like- minded people, following the homophily concept, wherein the degree of specialisation of the network, the topics, and/or its members, becomes a differential of the network. In other words, they are networks that are not for everybody, creating a sense of exclusivity. This sense of exclusivity is supported by the self-status seeking gratification, as people search actively to be recognised by the people they try to identify with. A niche SNS makes it possible for users to showcase their expertise, offering users a platform on which to propose new ideas that can be improved by others. Thus, a niche SNS allows the user to establish a reputation among people related to their interest, which could be difficult to reach in general purpose SNS. In the same vein, learning and innovativeness gratifications can be used by niche SNS managers to encourage participation among users, as these networks are places where they can be inspired to do new things or to go for innovative ideas and learn how to do it, which can be exemplified with academic SNS such as academia or research gate, who are niche SNS for academics.

\subsection{Research Implications and Further Research}

This proposed approach to adopt general purpose constructs and test them in a niche SNS context was able to explain $41.2 \%$ of the variance of the dependent variable. Although such a result could be considered as a good starting point, shedding light on the motivations to participate in niche SNS, it also calls for more research to be undertaken in this area. Future efforts can help increase the predictive power of the model by including new variables that could be relevant to niche SNS. Another stream of research is the type of users in niche SNS, which is guided by the research of Constantinides et al, (2010), Constantinides and Stagno (2011), Kilian et al, (2012), Brandtzæg (2012) and Bulut and Dogan (2017), who found that different types of users have different motivations to use SNS. Consequently, it would be interesting to study the type of users and their proportion in niche SNS. Due to the difficulties of accessing primary sources, it is recommended that qualitative research approaches be used in order to gain a deeper understanding of these networks. Such an approach could potentially help identify a wider list of influential factors to test in a quantitative manner, within models like the one adopted for this research. A case study approach may also be useful for gaining insights into specific niche networks considering different types of networks, e.g. based on objectives, audiences, geographical attributes etc. 


\section{REFERENCES}

Ajzen, I. (1991). The theory of planned behavior. Organizational Behavior and Human Decision Processes, 50(2), 179-211. doi:10.1016/0749-5978(91)90020-T

Ali-Hassan, H., Nevo, D., \& Wade, M. (2015). Linking dimensions of social media use to job performance: The role of social capital. The Journal of Strategic Information Systems, 24(2), 65-89. doi:10.1016/j.jsis.2015.03.001

Bae, M. (2018). Understanding the effect of the discrepancy between sought and obtained gratification on social networking site users' satisfaction and continuance intention. Computers in Human Behavior, 79, 137-153. doi:10.1016/j.chb.2017.10.026

Baek, K., Holton, A., Harp, D., \& Yaschur, C. (2011). The links that bind: Uncovering novel motivations for linking on Facebook. Computers in Human Behavior, 27(6), 2243-2248. doi:10.1016/j.chb.2011.07.003

Bhappu, A., \& Schultze, U. (2018). Implementing an Organization-sponsored Sharing Platform to Build Employee Engagement. MIS Quarterly Executive.

Boyd, D. M., \& Ellison, N. B. (2008). Social Network Sites: Definition, History, and Scholarship. Journal of Computer-Mediated Communication, 13(1), 210-230. doi:10.1111/j.1083-6101.2007.00393.x

Brandtzæg, P. B. (2012). Social networking sites: Their users and social implications - A longitudinal study. Journal of Computer-Mediated Communication, 17(4), 467-488. doi:10.1111/j.1083-6101.2012.01580.x

Bulut, Z. A., \& Doğan, O. (2016, January). The ABCD typology: Profile and motivations of Turkish social network sites users. Computers in Human Behavior, 67, 73-83. doi:10.1016/j.chb.2016.10.021

Calero Valdez, A., Brell, J., Schaar, A. K., \& Ziefle, M. (2018). The diversity of why: A meta-analytical study of usage motivation in enterprise social networks. Universal Access in the Information Society, 17(3), 549-566. doi:10.1007/s10209-017-0561-9

Carman, A. (2018). Fake Instagrams are one of the last refuges of the authentic online self. The verge. Retrieved from https://www.theverge.com/2018/4/3/17189912/fake-instagram-finsta-account-whyd-you-push-that-button

Castillo, M. (2018). Facebook's North American daily active users stay flat after scandals. Retrieved September 13, 2018, from https://www.cnbc.com/2018/07/25/facebooks-north-american-daily-active-users-after-scandals. html

Cha, J. (2010). Factors affecting the frequency and amount of social networking site use: Motivations, perceptions, and privacy concerns. First Monday, 15.

Chang, L., \& Chen, J. V. (2014). Aligning principal and agent's incentives: A principal-agent perspective of social networking sites. Expert Systems with Applications, 41(6), 3091-3104. doi:10.1016/j.eswa.2013.10.040

Chen, A., Lu, Y., \& Wang, B. (2016). Enhancing perceived enjoyment in social games through social and gaming factors. Information Technology \& People, 29(1), 99-119. doi:10.1108/ITP-07-2014-0156

Chen, Y. F. (2014). See you on Facebook: Exploring influences on Facebook continuous usage. Behaviour \& Information Technology, 33(11), 1208-1218. doi:10.1080/0144929X.2013.826737

Cheung, C. M. K., Chiu, P.-Y., \& Lee, M. K. O. (2011). Online social networks: Why do students use facebook? Computers in Human Behavior, 27(4), 1337-1343. doi:10.1016/j.chb.2010.07.028

Chiu, C.-M., \& Huang, H.-Y. (2015a). Examining the antecedents of user gratification and its effects on individuals' social network services usage: The moderating role of habit. European Journal of Information Systems, 24(4), 411-430. doi:10.1057/ejis.2014.9

Chiu, C. M., \& Huang, H. Y. (2015b). Examining the antecedents of user gratification and its effects on individuals' social network services usage: The moderating role of habit. European Journal of Information Systems, 24(4), 411-430. doi:10.1057/ejis.2014.9

Chung, N., Koo, C., \& Park, S.-B. (2012). Why People Share Information in Social Network Sites? Integrating with Uses and Gratification and Social Identity Theories. In J.-S. Pan, S.-M. Chen, \& N. Nguyen (Eds.), Intelligent Information and Database Systems. Springer Berlin Heidelberg. doi:10.1007/978-3-642-28490-8_19 
Chung, N., Nam, K., \& Koo, C. (2015). Examining information sharing in social networking communities: Applying theories of social capital and attachment. Telematics and Informatics, 33(1), 77-91. doi:10.1016/j. tele.2015.05.005

Chunngam, B., Chanchalor, S., \& Murphy, E. (2014). Membership, participation and knowledge building in virtual communities for informal learning. British Journal of Educational Technology, 45(5), 863-879. doi:10.1111/bjet.12114

Cocosila, M., \& Igonor, A. (2015). How important is the "social" in social networking? A perceived value empirical investigation. Information Technology \& People, 28(2), 366-382. doi:10.1108/ITP-03-2014-0055

Constantinides, E., Amo, M., Del C. A., \& Romero, C. L. (2010). Profiles of Social Networking Sites Users in the Netherlands. 18th Annual High Technology Small Firms Conference. Retrieved from http://purl.utwente.nl/ publications/73399

Crawford, S., Hall, M., Gray, W., Johnson, B., \& Price, R. A. (2017). What motivates buy-side analysts to share recommendations online? Management Science, 64(6), 2473-2972.

Dimmick, J., Kline, S., \& Stafford, L. (2000). The Gratification Niches of Personal E-mail and the Telephone Competition, Displacement, and Complementarity. Communication Research, 27(2), 227-248. doi: $10.1177 / 009365000027002005$

Dimmick, J., Ramirez, A. Jr, Wang, T., \& Lin, S. F. (2007). Extending society: The role of personal networks and gratification-utilities in the use of interactive communication media. New Media \& Society, 9(5), 795-810. doi: $10.1177 / 1461444807081225$

Ellison, N., Heino, R., \& Gibbs, J. (2006). Managing Impressions Online: Self-Presentation Processes in the Online Dating Environment. Journal of Computer-Mediated Communication, 11(2), 415-441. doi:10.1111/j.10836101.2006.00020.x

Ellison, N. B., Steinfield, C., \& Lampe, C. (2007). The benefits of facebook "friends:" Social capital and college students' use of online social network sites. Journal of Computer-Mediated Communication, 12(4), 1143-1168. doi:10.1111/j.1083-6101.2007.00367.x

Fishbein, M., \& Ajzen, I. (1975). Belief, attitude, intention and behavior: An introduction to theory and research. Academic Press.

Foregger, S. K. (2008). Uses and gratifications of Facebook.com. Michigan State University.

Gan, C., \& Wang, W. (2015). Uses and gratifications of social media: A comparison of microblog and WeChat. Journal of Systems and Information Technology, 17(4), 351-363. doi:10.1108/JSIT-06-2015-0052

Giannakos, M. N., Chorianopoulos, K., Giotopoulos, K., \& Vlamos, P. (2013). Using Facebook out of habit. Behaviour \& Information Technology, 32(6), 594-602. doi:10.1080/0144929X.2012.659218

Gironda, J. T., \& Korgaonkar, P. K. (2014). Understanding consumers' social networking site usage. Journal of Marketing Management, 30(5-6), 571-605. doi:10.1080/0267257X.2013.851106

Goggins, S. P., Laffey, J., \& Gallagher, M. (2011). Completely online group formation and development: Small groups as socio-technical systems. Information Technology \& People, 24(2), 104-133. doi:10.1108/09593841111137322

Hajli, N., Shanmugam, M., Powell, P., \& Love, P. E. D. (2015). A study on the continuance participation in on-line communities with social commerce perspective. Technological Forecasting and Social Change, 96, 232-241. doi:10.1016/j.techfore.2015.03.014

Hewson, C., \& Laurent, D. (2012). Research design and tools for internet research. In N. G. Fielding, R. M. Lee, \& G. Blank (Eds.), Sage Internet Research Methods. SAGE.

Hou, J. (2011). Uses and gratifications of social games: Blending social networking and game play. First Monday, 16.

Hsu, M. H., Tien, S. W., Lin, H. C., \& Chang, C. M. (2015). Understanding the roles of cultural differences and socio-economic status in social media continuance intention. Information Technology \& People, 28(1), 224-241. doi:10.1108/ITP-01-2014-0007 
Hsu, T.-H., Wang, Y.-S., \& Wen, S. (2006). Using the decomposed theory of planning behavioural to analyse consumer behavioural intention towards mobile text message coupons. Journal of Targeting. Measurement and Analysis for Marketing, 14(4), 309-324. doi:10.1057/palgrave.jt.5740191

Huang, E. (2008). Use and gratification in e-consumers. Internet Research, 18(4), 405-426. doi:10.1108/10662240810897817

Huang, L. C., \& Shiau, W. L. (2015). Why do people use microblogs? An empirical study of Plurk. Information Technology \& People, 28(2), 281-303. doi:10.1108/ITP-07-2012-0067

Joinson, A. N. 2008. Looking at, looking up or keeping up with people?: motives and use of facebook. Proceeding of the twenty-sixth annual SIGCHI conference on Human factors in computing systems. Florence, Italy: ACM. doi:10.1145/1357054.1357213

Kang, J.-Y. M., \& Johnson, K. K. (2015). F-Commerce platform for apparel online social shopping: Testing a Mowen's 3M model. International Journal of Information Management, 35(6), 691-701. doi:10.1016/j. ijinfomgt.2015.07.004

Katz, E., Blumler, J. G., \& Gurevitch, M. (1973). Uses and Gratifications Research. Public Opinion Quarterly, 37(4), 509-523. doi:10.1086/268109

Kilian, T., Hennigs, N., \& Langner, S. (2012). Do Millennials read books or blogs? Introducing a media usage typology of the internet generation. Journal of Consumer Marketing, 29(2), 114-124. doi: $10.1108 / 07363761211206366$

Kim, J. H., Kim, M. S., \& Nam, Y. (2010). An Analysis of Self-Construals, Motivations, Facebook Use, and User Satisfaction. International Journal of Human-Computer Interaction, 26(11-12), 1077-1099. doi:10.108 0/10447318.2010.516726

Kim, M., \& Cha, J. (2017, October). A comparison of Facebook, Twitter, and LinkedIn: Examining motivations and network externalities for the use of social networking sites. First Monday.

Kim, M. J., Lee, C. K., \& Bonn, M. (2016). The effect of social capital and altruism on seniors' revisit intention to social network sites for tourism-related purposes. Tourism Management, 53, 96-107. doi:10.1016/j. tourman.2015.09.007

Kim, Y., Sohn, D., \& Choi, S. M. (2011). Cultural difference in motivations for using social network sites: A comparative study of American and Korean college students. Computers in Human Behavior, 27(1), 365-372. doi:10.1016/j.chb.2010.08.015

Kourouthanassis, P., Lekakos, G., \& Gerakis, V. (2015). Should i stay or should i go? the moderating effect of self-image congruity and trust on social networking continued use. Behaviour \& Information Technology, 34(2), 190-203. doi:10.1080/0144929X.2014.948489

Krasnova, H., Hildebrand, T., Günther, O., Kovrigin, A., \& Nowobilska, A. (2008). Why participate in an online social network: an empirical analysis. 16th European Conference on Information Systems ECIS, Galway, Ireland.

Krasnova, H., Veltri, N.F., Eling, N., \& Buxmann, P. (2017). Why men and women continue to use social networking sites: The role of gender differences. Journal of Strategic Information Systems, 26(4), 261-284.

Kwon, H. E., Oh, W., \& Kim, T. (2017). Platform Structures, Homing Preferences, and Homophilous Propensities in Online Social Networks. Journal of Management Information Systems, 34(3), 768-802. doi:10.1080/07421 222.2017.1373008

Kwon, O., \& Wen, Y. (2010). An empirical study of the factors affecting social network service use. Computers in Human Behavior, 26(2), 254-263. doi:10.1016/j.chb.2009.04.011

Lampe, C., Ellison, N., \& Steinfield, C. (2006). A Face(book) in the crowd: Social searching vs. social browsing. ACM. doi:10.1145/1180875.1180901

Lee, J. H., Kim, J. H., \& Hong, J. H. (2010). A comparison of adoption models for new mobile media services between high- and low-motive groups. International Journal of Mobile Communications, 8(5), 487-506. doi:10.1504/IJMC.2010.034934 
Leskovec, J., Backstrom, L., Kumar, R., \& Tomkins, A. 2008. Microscopic evolution of social networks. In Proceeding of the 14th ACM SIGKDD international conference on Knowledge discovery and data mining. Las Vegas, NV: ACM. doi:10.1145/1401890.1401948

Li, X., Chen, W. \& Popiel, P. (2015). What happens on Facebook stays on Facebook? The implications of Facebook interaction for perceived, receiving, and giving social support. Computers in Human Behavior, 51(A), 106-113.

Lim, V., Frangakis, N., Tanco, L. M., \& Picinali, L. (2018). PLUGGY: A Pluggable Social Platform for Cultural Heritage Awareness and Participation. Lecture Notes in Computer Science, 10754, 117-129. doi:10.1007/9783-319-75789-6_9

Lingreen, A., Dobele, A., Vanhamme, J., Luís Abrantes, J., Seabra, C., Raquel Lages, C., \& Jayawardhena, C. (2013). Drivers of in-group and out-of-group electronic word-of-mouth (eWOM). European Journal of Marketing, 47(7), 1067-1088. doi:10.1108/03090561311324219

Lorenzo-Romero, C., Constantinides, E., \& Alarcón-Del-Amo, M. (2011). Consumer adoption of social networking sites: Implications for theory and practice. Journal of Research in Interactive Marketing, 5(2/3), 170-188. doi:10.1108/17505931111187794

Mehdizadeh, S. (2010). Self-presentation 2.0: Narcissism and self-esteem on Facebook. Cyberpsychology, Behavior, and Social Networking, 13(4), 357-364. doi:10.1089/cyber.2009.0257 PMID:20712493

Mital, M., \& Sarkar, S. (2011). Multihoming behavior of users in social networking web sites: A theoretical model. Information Technology \& People, 24(4), 378-392. doi:10.1108/09593841111182250

Nadkarni, A., \& Hofmann, S. G. (2011). Why do people use Facebook? Personality and Individual Differences. PMID:22544987

Nyland, R. (2007). The Gratification Niches of Online Social Networking, E-Mail and Face-to-Face Communication (Master's Thesis). Brigham Young University.

Pai, P., \& Arnott, D. C. (2012). User adoption of social networking sites: Eliciting uses and gratifications through a means-end approach. Computers in Human Behavior.

Papacharissi, Z., \& Rubin, A. M. (2000). Predictors of Internet Use. Journal of Broadcasting \& Electronic Media, 44(2), 175-196. doi:10.1207/s15506878jobem4402_2

Park, C., Jun, J., \& Lee, T. (2015). Consumer characteristics and the use of social networking sites: A comparison between Korea and the US. International Marketing Review, 32(3/4), 414-437. doi:10.1108/IMR-09-2013-0213

Park, J. H., Gu, B., Leung, A. C. M., \& Konana, P. (2014). An investigation of information sharing and seeking behaviors in online investment communities. Computers in Human Behavior, 31, 1-12. doi:10.1016/j. chb.2013.10.002

Park, N., Kee, K. F., \& Valenzuela, S. (2009). Being Immersed in Social Networking Environment: Facebook Groups, Uses and Gratifications, and Social Outcomes. Cyberpsychology \& Behavior, 12(6), 729-733. doi:10.1089/cpb.2009.0003 PMID:19619037

Phua, J., Jin, S. V., \& Kim, J. (2017). Uses and gratifications of social networking sites for bridging and bonding social capital: A comparison of Facebook, Twitter, Instagram, and Snapchat. Computers in Human Behavior, 72, 115-122. doi:10.1016/j.chb.2017.02.041

Pugh, J. L. (2010). A Qualitative Study of the Facebook Social Network: the desire to influence, associate, and construct a representative and ideal identity. College of Business Administration Honors Program at California State University. Long Beach, CA: Mayıs.

Raacke, J., \& Bonds-Raacke, J. (2008). MySpace and Facebook: Applying the uses and gratifications theory to exploring friend-networking sites. Cyberpsychology \& Behavior, 11(2), 169-174. doi:10.1089/cpb.2007.0056 PMID:18422409

Ramirez, A. Jr, Dimmick, J., Feaster, J., \& Lin, S. F. (2008). Revisiting Interpersonal Media Competition The Gratification Niches of Instant Messaging, E-Mail, and the Telephone. Communication Research, 35(4), 529-547. doi:10.1177/0093650208315979 
Ridings, C. M. \& Gefen, D. (2004). Virtual Community Attraction: Why People Hang Out Online. Journal of Computer-Mediated Communication, 10.

Rogers, E. M. (2003). Diffusion of Innovations (5th ed.). Free Press.

Rubin, A. M. (2002). The uses-and-gratifications perspective of media effects. In J. Bryant \& M. B. Oliver (Eds.), Media effects: advances in theory and research. Routledge.

Sangwan, S. (2005). Virtual Community Success: A Uses and Gratifications Perspective. System Sciences, 2005. HICSS '05. Proceedings of the 38th Annual Hawaii International Conference on. doi:10.1109/HICSS.2005.673

Schau, H. J., \& Gilly, M. C. (2003). We are what we post? Self-presentation in personal web space. The Journal of Consumer Research, 30(3), 385-404. doi:10.1086/378616

Shen, G. C. (2015). How quality of life affects intention to use social networking sites: Moderating role of selfdisclosure. Journal of Electronic Commerce Research, 16, 276-289.

Smock, A. D., Ellison, N. B., Lampe, C., \& Wohn, D. Y. (2011). Facebook as a toolkit: A uses and gratification approach to unbundling feature use. Computers in Human Behavior, 27(6), 2322-2329. doi:10.1016/j. chb.2011.07.011

Syn, S. Y., \& Oh, S. (2015). Why do social network site users share information on Facebook and Twitter? Journal of Information Science, 41(5), 553-569. doi:10.1177/0165551515585717

Tan, C. H., Sutanto, J., \& Tan, B. C. Y. (2015). Empirical investigation on relational social capital in a virtual community for website programming. The Data Base for Advances in Information Systems, 46(2), 43-60. doi:10.1145/2795618.2795622

The Guardian. (2017). Finstagram - a secret Instagram account to post ugly selfies. The Guardian. Retrieved from https://www.theguardian.com/technology/shortcuts/2017/feb/21/finstagram-secret-instagram-accountpost-ugly-selfies

Tosun, L. P. (2012). Motives for Facebook use and expressing "true self" on the Internet. Computers in Human Behavior, 28(4), 1510-1517. doi:10.1016/j.chb.2012.03.018

Wei, H. L., Lin, K. Y., Lu, H. P., \& Chuang, I. H. (2015). Understanding the intentions of users to 'stick' to social networking sites: A case study in Taiwan. Behaviour \& Information Technology, 34(2), 151-162. doi:1 0.1080/0144929X.2014.928745

Welch, C. (2018). More people are taking Facebook breaks and deleting the app from their phones. The Verge. Retrieved September 13, 2018, from https://www.theverge.com/2018/9/5/17822736/facebook-break-delete-app

Wilson, R. E., Gosling, S. D., \& Graham, L. T. (2012). A Review of Facebook Research in the Social Sciences. Perspectives on Psychological Science, 7(3), 203-220. doi:10.1177/1745691612442904 PMID:26168459

Wong, W. K.-W. (2012). Faces on Facebook: A study of self-presentation and social support on Facebook. Run Run Shaw Library, City University of Hong Kong.

Xu, C., Ryan, S., Prybutok, V., \& Wen, C. (2012). It is not for fun: An examination of social network site usage. Information \& Management, 49(5), 210-217. doi:10.1016/j.im.2012.05.001

Xu, Y. C., Yang, Y., Cheng, Z., \& Lim, J. (2014). Retaining and attracting users in social networking services: An empirical investigation of cyber migration. The Journal of Strategic Information Systems, 23(3), $239-253$. doi:10.1016/j.jsis.2014.03.002

Yang, H.-L., \& Lin, C.-L. (2014). Why do people stick to Facebook web site? A value theory-based view. Information Technology \& People, 27(1), 21-37. doi:10.1108/ITP-11-2012-0130

Yen, C. (2016). How to unite the power of the masses? Exploring collective stickiness intention in social network sites from the perspective of knowledge sharing. Behaviour \& Information Technology, 35(2), 118-133. doi:1 0.1080/0144929X.2015.1105297

Zhao, S., Grasmuck, S., \& Martin, J. (2008). Identity construction on Facebook: Digital empowerment in anchored relationships. Computers in Human Behavior, 24(5), 1816-1836. doi:10.1016/j.chb.2008.02.012 
Zhu, D. H., Chang, Y. P., Luo, J. J., \& Li, X. (2014). Understanding the adoption of location-based recommendation agents among active users of social networking sites. Information Processing \& Management, 50(5), 675-682. doi:10.1016/j.ipm.2014.04.010

Zolkepli, I. A., \& Kamarulzaman, Y. (2015). Social media adoption: The role of media needs and innovation characteristics. Computers in Human Behavior, 43, 189-209. doi:10.1016/j.chb.2014.10.050

Carlos Andres Osorio received PhD in Business from Newcastle University, currently working as senior lecturer in digital marketing at the University of Manizales (Colombia).

Savvas Papagiannidis is the David Goldman Professor of Innovation and Enterprise in the Newcastle University Business School, UK. His work has been published in several academic journals and presented at international conferences. His research interests mainly revolve around electronic business and its various sub-domains. More specifically, his research aims to inform our understanding of how e-business technologies affect the social and business environment, organisational strategies and business models, and how these are implemented in terms of functional innovations. His work puts strong emphasis on innovation, new value creation and the exploitation of entrepreneurial opportunities, within the context of different industries. 